Matus Danko - Juraj Adamec - Peter Drgona - Michal Frivaldsky

\title{
RECOVERY PROCEDURE FOR DEEPLY DISCHARGED LIFEP0, TRACTION BATTERY
}

Presented paper deals with possibility of recovery of damaged traction batteries by deep discharge. For the test of proposed charging algorithm, new, unused cell was selected, the deeply discharged condition of which was caused by the self-discharge during the improper storage. The cell had significant damage of package in the central part. For the battery testing, experimental set-up was realized for automated recovering procedure and other tests of cells. For verification of the proposed algorithm, a recovered cell was compared to a reference/new cell by testing the delivered ampere-hours for various discharging current. The final evaluation shows that the proposed algorithm for recovery of the deeply discharged cell can recover up to \%0\% of the nominal cell capacity.

Keywords: traction battery, deep discharge, battery recovery, $\mathrm{LiFePO}_{4}$

\section{Introduction}

Lifetime of lithium batteries can be divided into four phases. The first phase starts at production, where batteries are made and tested. If the test failed, batteries are directly recycled. Batteries are produced as uncharged, whereupon batteries must be charged before the first use, which is the next and most important phase of the battery lifetime. Initial charging and discharging are called formatting and has significant impact on the battery performance. The most important parameters during the formation are number of charging/discharging cycles, battery current and battery voltage. This process is executed by the manufacturer during the manufactured batteries testing. Those tests are performed in order to detect bad batteries with lower capacity. Most often, batteries are discharged to $50 \%$ of capacity and stored several weeks for testing the self-discharge and open circuit voltage (OCV) is measured. Batteries, capacity of which falls below $47 \%$, fails the test and are recycled. The next phase is using batteries in application, which has significant impact on the battery lifetime, based on charging/discharging current, charging voltage and other parameters, [1-3]. The next conditions, which can impact the battery lifetime are overcharging or over-discharging. End of the battery lifetime is the last phase and usually occurs at $80 \%$ of state of health of a battery. Batteries can be recycled by various methods, based on the battery chemistry. For the lead acid batteries, about $99 \%$ of lead from used batteries is reclaimed. From the lithium-ion batteries, lithium-iron-phosphate (LiFePO4) is possible to recycle for up to $80 \%$ of the batteries' material, [4-6]. Depending on the battery active materials, it is possible to recover cobalt, manganese and nickel for reuse in producing new batteries. However, manufacturing batteries from the recycled materials is five times more expensive than manufacturing from the new ones, so for many manufacturers it is more cost-effective to produce batteries from the new materials, [7-10].

After the battery's state of health falls to $80 \%$ and battery is not suitable for original application, it is possible to continue using it in other application where demands on battery performance are not high, for example in storage for photovoltaics, [9-11]. Recovery of damaged batteries as well as recycling is therefore a topic, which must be accepted if sustainability related to environment and costs are considered, [12-14]. Therefore, within the presented paper, the experimental methodology for deeply discharged battery recovery is being introduced.

\section{Selected cell and test-stand}

For testing of the battery recovery algorithm, WINA $3.2 \mathrm{~V}$ 60Ah $\mathrm{LiFePO} 4$ cell was selected. Parameters of the cell are listed in Table 1 . This cell has significant damage of package in central part of the cell. The width of the cell reached $43.8 \mathrm{~mm}$ while the width of the new cell, specified by manufacturer is $36 \mathrm{~mm}$, (Figure 1). The deep discharge condition was confirmed by measurement of the open circuit voltage, which was only $2.04 \mathrm{~V}$. The minimal voltage of the selected cell in datasheet is $2.5 \mathrm{~V}$. Selected cell was new, unused and its deep discharge was caused by improper storage and cell voltage decreased below the minimal cell voltage because of the self-discharge. The permissible selfdischarge, specified by the cell manufacturer is a loss of $3 \%$ of capacity over a month period, [15].

Matus Danko, Juraj Adamec, Peter Drgona, Michal Frivaldsky*

Department of Mechatronics and Electronics, Faculty of Electrical Engineering and Information Technologies, University of Zilina, Slovakia

E-mail of corresponding author: michal.frivaldsky@feit.uniza.sk 


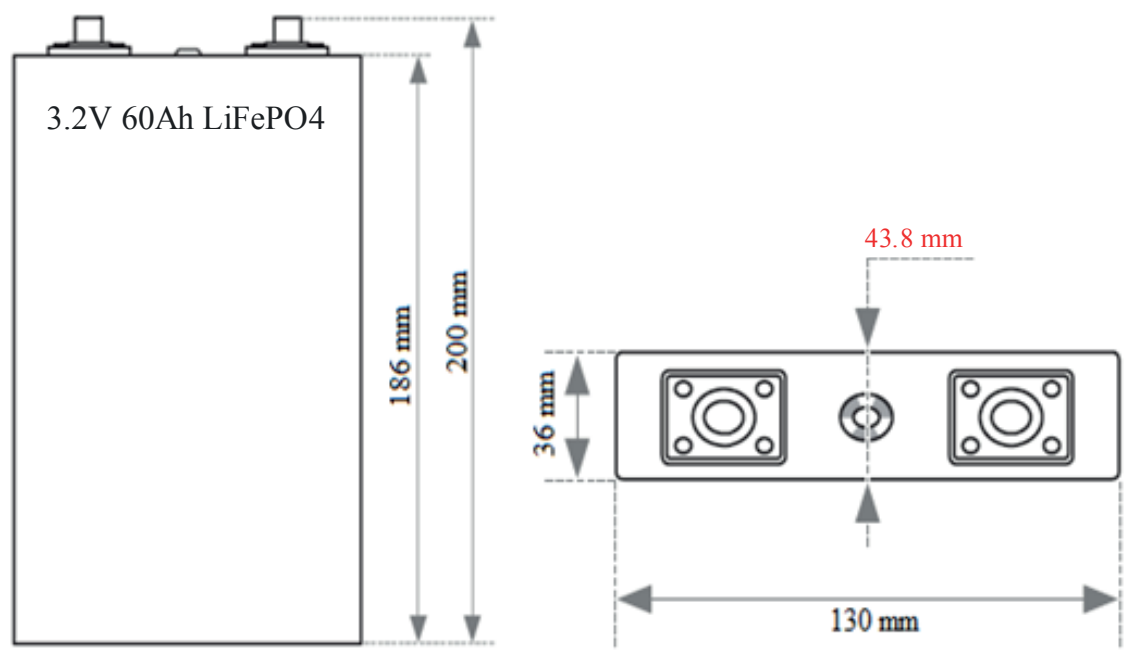

Figure 1 Dimensions defined by manufacturer and change of width in the central part

Table 1 Technical parameters of investigated cell WINA LiFePO $3.2 \mathrm{~V} 60 \mathrm{Ah}$

\begin{tabular}{|c|c|c|}
\hline Parameters & Value & unit \\
\hline Nominal voltage & 3.2 & {$[\mathrm{~V}]$} \\
\hline Maximum charging voltage & 3.8 & {$[\mathrm{~V}]$} \\
\hline Minimum voltage & 2.5 & {$[\mathrm{~V}]$} \\
\hline $\begin{array}{l}\text { Maximum discharge current } \\
\text { (continuous) }\end{array}$ & 3 & {$[\mathrm{C}]$} \\
\hline Optimal discharge current & 20 & {$[\mathrm{~A}]$} \\
\hline Maximum charging current & 90 & {$[\mathrm{~A}]$} \\
\hline Optimal charging current & 20 & {$[\mathrm{~A}]$} \\
\hline Operating temperature & -20 to +50 & {$\left[\mathrm{C}^{\circ}\right]$} \\
\hline Capacity & 60 & [Ah] \\
\hline Shell material (package) & aluminum & {$[-]$} \\
\hline
\end{tabular}

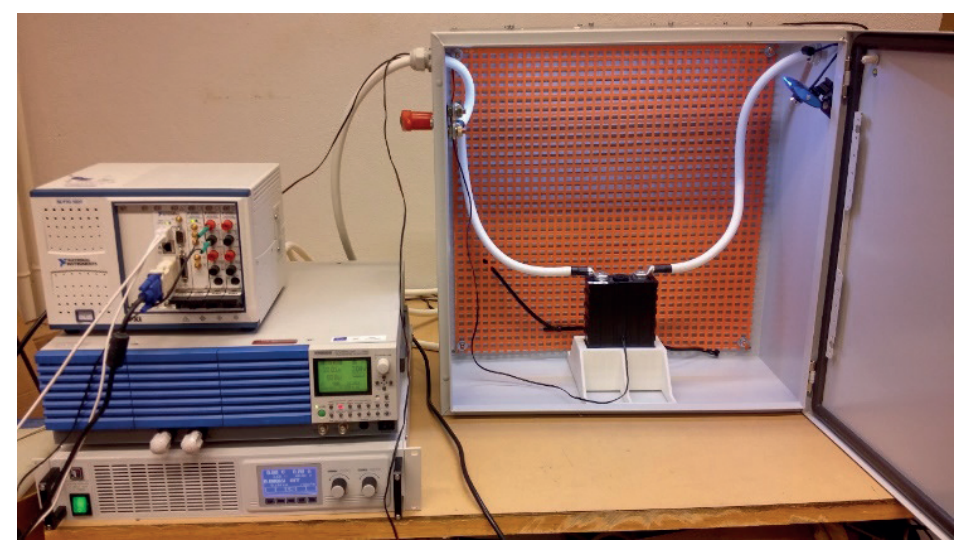

Figure 2 Experimental test-stand for the traction batteries recovery

\subsection{The test-stand for battery recovery testing}

To secure safety, the recovery procedure and other tests of traction batteries were executed on a designed test stand, which can be seen in Figures 2 and 3. The test stand consists of a metal box where the battery is located, programmable power supply EA PSI 8080-60, programmable electronic load KIKOSUI PLZ 100W and NI PXI-1031 for control, temperature measurement and logging (current/ voltage/temperature). To prevent the hazardous situation, the power line of a battery is protected by a mechanical switch. By using the LabVIEW application of NI PXI it is possible to create a sequence of charging or discharging of the cell. 


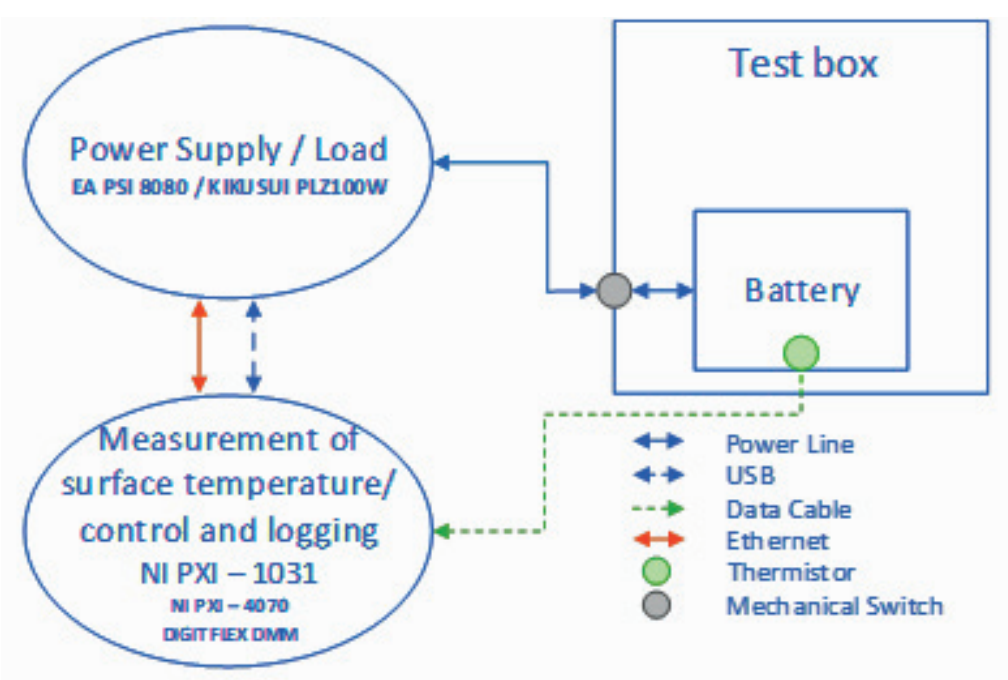

Figure 3 Block diagram of the test-stand for the traction batteries recovery

Table 2 Setting of sequences of regeneration algorithm for deeply discharged cell

\begin{tabular}{|c|c|c|c|}
\hline & Duration & Amplitude of charging current & Charging voltage \\
\hline Sequence & $\begin{array}{l}126 \mathrm{~min} \\
\text { consists of subsequences } 1 \text { and } 2\end{array}$ & $20 \mathrm{~A}$ & $3.65 \mathrm{~V}$ \\
\hline Subsequence 1 & $\begin{array}{c}30 \text { charging pulses } \\
30 \text { pause pulses } \\
\text { alternating } \\
\text { one pulse = } 1 \text { second }\end{array}$ & & \\
\hline Subsequence 2 & $\begin{array}{l}\text { Regeneration period } \\
\qquad 5 \mathrm{~min}\end{array}$ & & \\
\hline
\end{tabular}

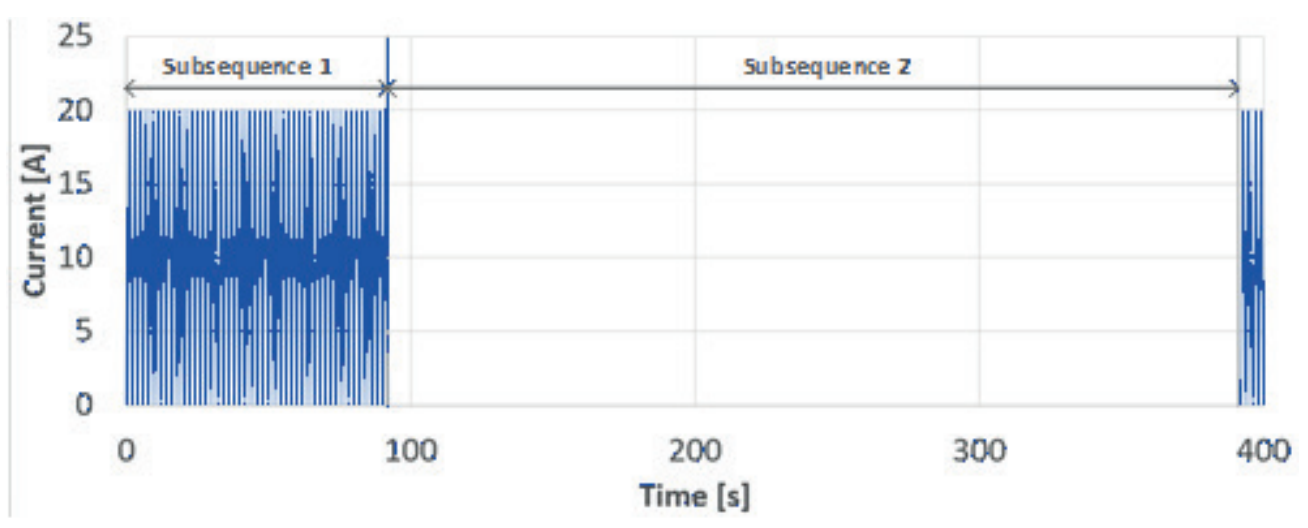

Figure 4 Graphical interpretation of proposed regeneration sequence for deeply discharged cells

\section{Charging algorithm for recovery of the deeply discharged cells}

Algorithm for recovery of the deeply discharged cells consists of 30 steps of charging and 30 steps of pause, mutually alternating, while each steps lasts 1 second (Figure 4). After that, battery is resting for 5 minutes for a cell to regenerate. The whole algorithm lasts 126 minutes; it consists of 21 sequences, as can be seen in Table 2 . Amplitude of the charging current was selected, following recommendation from manufacturer, to $20 \mathrm{~A}$, which is $1 / 3$ of capacity of a cell. Maximum of charging voltage was selected to $3.65 \mathrm{~V}$. For the given battery, application of six sequences was realized in order to achieve required OCV on the device, while 16 hours of resting period was applied between individual sequences.

Figures 5-7 show time waveform of the cell voltage during each sequence application. It is seen that voltage increased from $2.04 \mathrm{~V}$ up to $3.19 \mathrm{~V}$ at the end of the first sequence, while during the last sequence the voltage level 

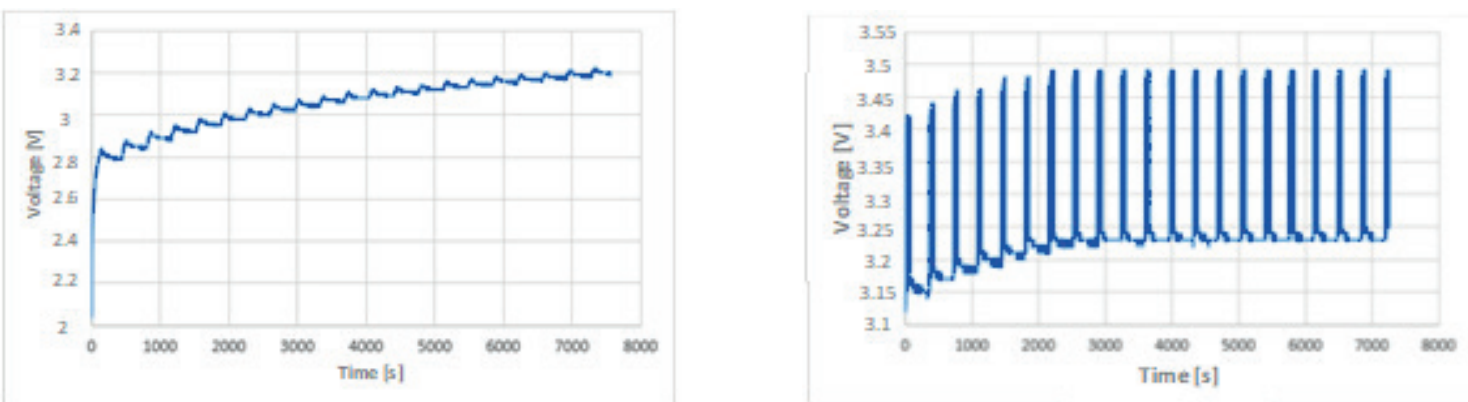

Figure 5 Voltages of cells during the first sequence (left) and second sequence (right) charging
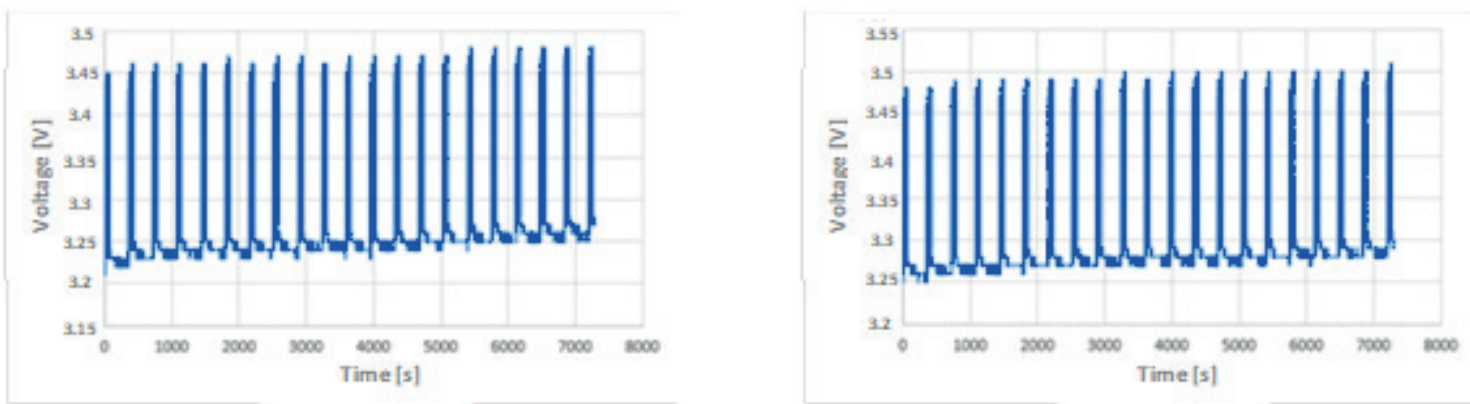

Figure 6 Voltages of cells during of the third sequence (left) and fourth sequence (right) charging
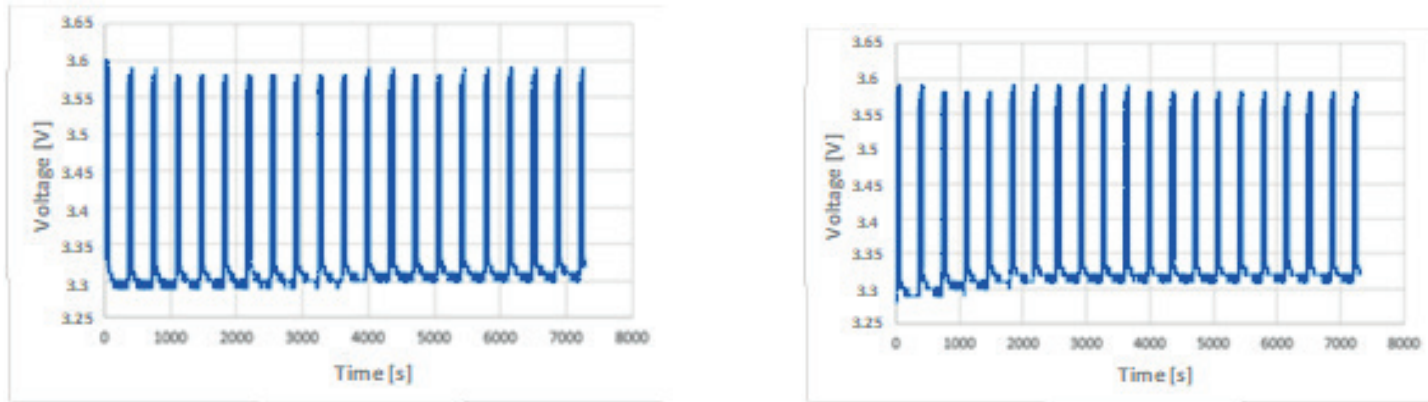

Figure 7 Voltages of cells during the fifth sequence (left) and sixth sequence (right) charging

Table 3 Voltage levels before and after each regeneration sequence of deeply discharged cell

\begin{tabular}{ccc}
\hline Sequence & $\begin{array}{c}\text { Voltage on a cell } \\
\text { before the sequence }\end{array}$ & $\begin{array}{c}\text { Voltage on a cell } \\
\text { after the sequence }\end{array}$ \\
\hline 1 & $2.04 \mathrm{~V}$ & $3.19 \mathrm{~V}$ \\
2 & $3.12 \mathrm{~V}$ & $3.21 \mathrm{~V}$ \\
3 & $3.19 \mathrm{~V}$ & $3.27 \mathrm{~V}$ \\
4 & $3.21 \mathrm{~V}$ & $3.28 \mathrm{~V}$ \\
5 & $3.24 \mathrm{~V}$ & $3.29 \mathrm{~V}$ \\
6 & $3.26 \mathrm{~V}$ & $3.31 \mathrm{~V}$ \\
\hline
\end{tabular}

on the cell exceeded $3.3 \mathrm{~V}$. Voltage of all the sequences are listed in Table 3. The temperature on the cell surface during each sequence was within $25.38{ }^{\circ} \mathrm{C}-26.18{ }^{\circ} \mathrm{C}$.

\section{Verification of the recovery algorithm}

Recovery was tested trough delivered ampere-hours. Before the testing, it is required to fully charge the recovered cell. Selected cell was charged by the CC\&CV (Constant
Current and Constant Voltage) method, with parameters for optimal charging from datasheet. Maximal charging current was $20 \mathrm{~A}$ as $1 / 3$ of capacity of cell and maximum charging voltage of cell $3.65 \mathrm{~V}$. The recovered cell is verified in a way of delivered ampere-hours test (test of capacity), whereby the new un-damaged cell has been used as a reference device for comparison and evaluation. For the test of the recovered cell capacity, five discharging currents have been verified i.e. $20 \mathrm{~A}, 40 \mathrm{~A}, 60 \mathrm{~A}, 80 \mathrm{~A}$. After each test, the cell was re-charged to full capacity, as mentioned above. 

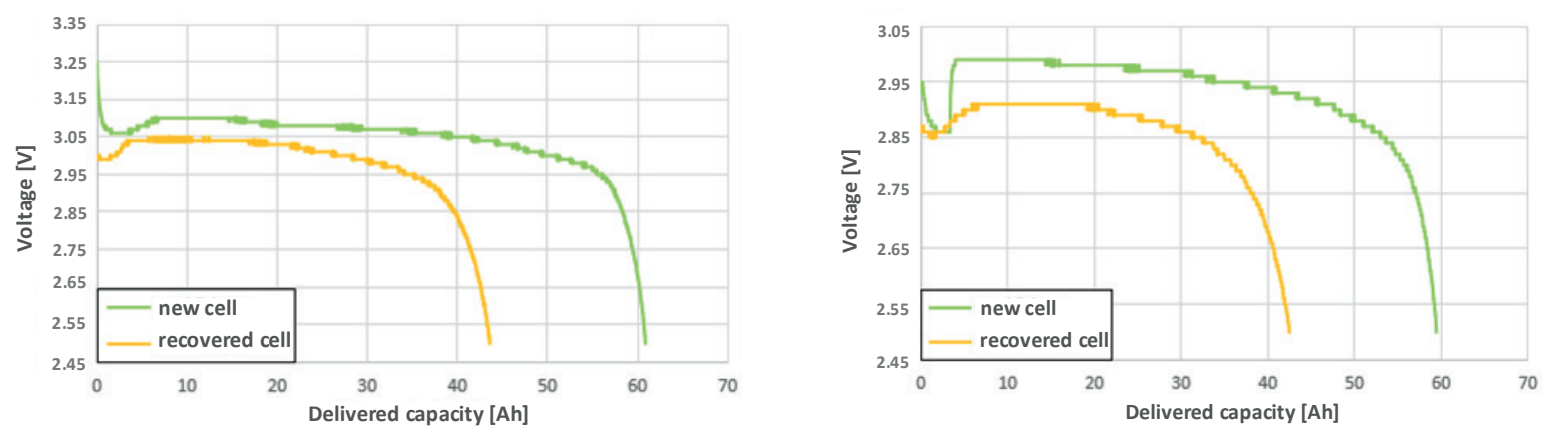

Figure 8 Cell voltage during the discharge by 20 A (left) and 40 A (right) for regenerated (yellow) and referenced cell (green)
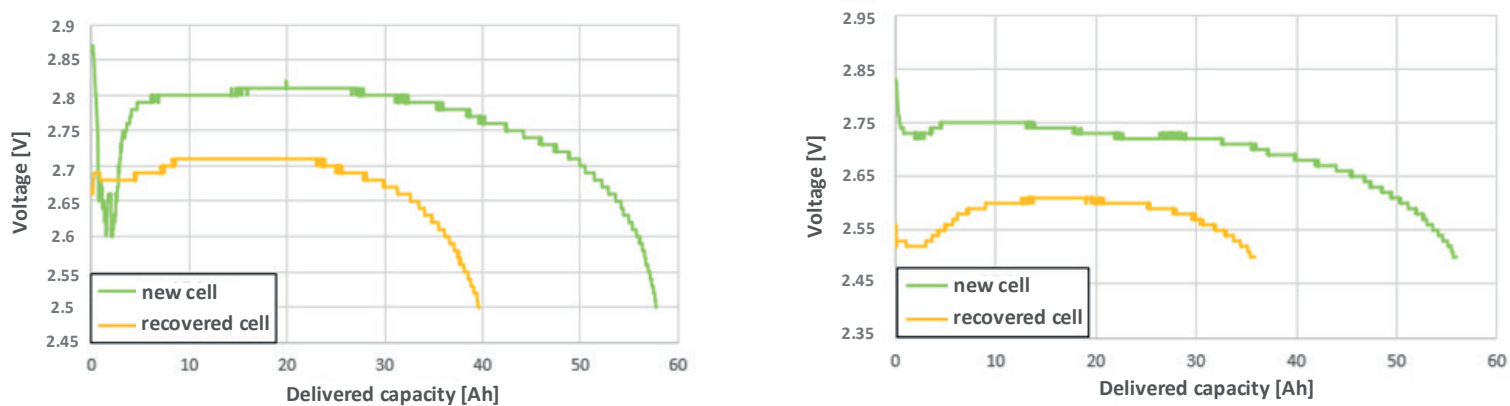

Figure 9 Cell voltage during the discharge by $60 \mathrm{~A}$ (left) and $80 \mathrm{~A}$ (right) for regenerated (yellow) and referenced cell (green)

Table 4 Summary of results of verification test of the deeply discharged cell

\begin{tabular}{|c|c|c|}
\hline Battery cell model & \multicolumn{2}{|c|}{$3,2 \mathrm{~V}, 60 \mathrm{Ah}, \mathrm{LiFePO}_{4}$} \\
\hline Cell status & Recovered after deep discharge & New cell \\
\hline \multicolumn{3}{|c|}{ Discharge CC $20 \mathrm{~A}$} \\
\hline discharge time & $2 \mathrm{~h}, 8 \mathrm{~min}, 18 \mathrm{~s}$ & $3 \mathrm{~h}, 2 \mathrm{~min}, 46 \mathrm{~s}$ \\
\hline maximal surface temperature & $31.293{ }^{\circ} \mathrm{C}$ & $35.397^{\circ} \mathrm{C}$ \\
\hline delivered Ah & $43.608 \mathrm{Ah}$ & $60.869 \mathrm{Ah}$ \\
\hline \multicolumn{3}{|c|}{ Discharge CC $40 \mathrm{~A}$} \\
\hline discharge time & $1 \mathrm{~h}, 2 \mathrm{~min}, 40 \mathrm{~s}$ & $1 \mathrm{~h}, 27 \mathrm{~min}, 18 \mathrm{~s}$ \\
\hline maximal surface temperature & $35.703{ }^{\circ} \mathrm{C}$ & $39.158^{\circ} \mathrm{C}$ \\
\hline delivered Ah & $42.536 \mathrm{Ah}$ & $59.486 \mathrm{Ah}$ \\
\hline \multicolumn{3}{|c|}{ Discharge CC $60 \mathrm{~A}$} \\
\hline discharge time & $38 \mathrm{~min}, 58 \mathrm{~s}$ & $57 \mathrm{~min}, 47 \mathrm{~s}$ \\
\hline maximal surface temperature & $38.403{ }^{\circ} \mathrm{C}$ & $41.502{ }^{\circ} \mathrm{C}$ \\
\hline delivered Ah & 39.709 Ah & $57.826 \mathrm{Ah}$ \\
\hline \multicolumn{3}{|c|}{ Discharge CC $80 \mathrm{~A}$} \\
\hline discharge time & $26 \mathrm{~min}, 22 \mathrm{~s}$ & $41 \mathrm{~min}, 4 \mathrm{~s}$ \\
\hline maximal surface temperature & $40.881{ }^{\circ} \mathrm{C}$ & $44.168^{\circ} \mathrm{C}$ \\
\hline delivered Ah & $35.886 \mathrm{Ah}$ & $55.965 \mathrm{Ah}$ \\
\hline
\end{tabular}

Delivered ampere-hours of the new cell, discharging with current $20 \mathrm{~A}$, was slightly higher than the nominal capacity of a cell, $60.869 \mathrm{Ah}$ and the surface temperature reached $35.397^{\circ} \mathrm{C}$. Delivered ampere-hours of the recovered cell was only $43.608 \mathrm{Ah}$, which is for 17.261 Ah less than the nominal capacity (Figure 8, left). The maximal temperature during the discharging was $31.293{ }^{\circ} \mathrm{C}$. At discharging current of $40 \mathrm{~A}$, the new cell delivered $49.468 \mathrm{Ah}$ and the surface temperature during the test was $39.158{ }^{\circ} \mathrm{C}$, while the recovered cell delivered only $42.536 \mathrm{Ah}$ (Figure 8, right), which is for $16.932 \mathrm{Ah}$ less and surface temperature reached was $35.703^{\circ} \mathrm{C}$. 
The third discharging current for the test was 60 A (Figure 9, left). At this discharge current, the new cell was able to deliver $57.862 \mathrm{Ah}$, while the recovered cell was able delivered only $39.709 \mathrm{Ah}$. The surface temperature of the new cell during the test was $41.502{ }^{\circ} \mathrm{C}$ and temperature of the recovered cell was $38.403{ }^{\circ} \mathrm{C}$. Difference of delivered ampere-hours in this case was $18.117 \mathrm{Ah}$. The last test was realized with discharging current 80 A (Figure 9, right). In this case, the new cell delivered $55.965 \mathrm{Ah}$ and the recovered cell delivered only $35.886 \mathrm{Ah}$. Temperature of the new cell during the test was $44.168{ }^{\circ} \mathrm{C}$ and temperature of the recovered cell was $40.881{ }^{\circ} \mathrm{C}$. Results of the tests are listed in Table 4.

\section{Conclusions}

This paper deals with the recovery algorithm of the lithium-iron-phosphate traction battery damaged by the deep discharge. Deeply discharged condition was caused by improper storage and it was confirmed by measurement of the open circuit voltage (OCV), which was only $2.04 \mathrm{~V}$, while the minimal voltage, specified by the manufacturer, should not drop below 2.5 V. The traction cell also had visible deformation in the central part, width in this part was $43.8 \mathrm{~mm}$, while width of the new cell, specified by the manufacturer, is $36 \mathrm{~mm}$. The recovery procedure is based on the charging process, whereby the deeply discharged cell uses short duration peak charging pulses. This charging algorithm was verified by test of the delivered ampere-hours. This test was realized with various discharging currents, i.e. 20, 40, 60 and $80 \mathrm{~A}$. The proposed recovery algorithm achieved almost 70\%, if the discharge currents were within $20-40 \mathrm{~A}(0.3 \mathrm{C}-0.6$ C). For the higher currents, the voltage drop of the battery represents the limiting parameters as it reached the minimum allowable operational value. The surface temperature of the recovered cell during the test was approximately for $10 \%$ lower than temperature of the new cell. During the recovery process and during the amperehours test, the battery deformation did not change.

\section{Acknowledgments}

The authors would like to thank to Slovak national grant agencies APVV and Vega for the financial support. This research was funded by APVV-15-0396 - and APVV-150571 . The experimental support was also supported by the project funding Vega 1/0547/18.

This publication was realized with support of Operational Program Integrated Infrastructure 2014 2020 of the project: Innovative Solutions for Propulsion, Power and Safety Components of Transport Vehicles, code ITMS 313011V334, co-financed by the European Regional Development Fund.

\section{References}

[1] REDDY, T. B., LINDEN, D. Linden's handbook of batteries. 4. ed. New York: McGraw-Hill Education, 2010. ISBN 978-0071624213.

[2] DENG, D. Li-ion batteries: basics, progress and challenges. Energy Science and Engineering [online]. 2015, 3(5), p. 385-418. eISSN 2050-0505. Available from: https://doi.org/10.1002/ese3.95

[3] KUHN, B. T., PITEL, G. E., KREIN, P. T. Electrical properties and equalization of lithium-ion cells in automotive applications. In: 2005 IEEE Vehicle Power and Propulsion Conference VPPC: proceedings [online]. 2005. Available from: https://doi.org/10.1109/VPPC.2005.1554532

[4] WESTERHOFF, U., KURBACH, K., UNGER, D., LOGES, H., HAUCK, D., LIENESCH, F., KURRAT, M., ENGEL, B. Evaluation of the entire battery life cycle with respect to the lithium-ion batteries. In: International ETG Congress: proceedings. Bonn, Germany: Die Energiewende - Blueprints for the new energy age, 2015. p. 1-7.

[5] SCROSATI, B. History of lithium batteries. Journal of Solid State Electrochemistry [online]. 2011, 15(7-8), p. $1623-1630$. ISSN 1432-8488. Available from: https://doi.org/https://doi.org/10.1007/s10008-011-1386-8

[6] BRODD, R. Batteries for sustainability: selected entries from the encyclopedia of sustainability science and technology [online]. New York: Springer-Verlag, 2013. ISBN 978-1-4614-5790-9, eISBN 978-1-4614-5791-6. Available from: https://doi.org/https://doi.org/10.1007/978-1-4614-5791-6

[7] ADITYA, P. J., FEROWSI M. Comparison of NiMh and Li-ion batteries in automotive applications. In: 2008 IEEE Vehicle Power and Propulsion Conference: proceedings [online]. IEEE, 2008. ISSN 1938-8756. Available from: https://doi.org/https://doi.org/10.1109/VPPC.2008.4677500

[8] YOO, H. D., MARKEVICH, E., SALTA, G., SHARON, D., AURBACH, D. On the challenge of developing advanced technologies for electrochemical energy storage and conversion. Materials Today [online]. 2014, 17(3), p. 110-121. ISSN 1369-7021. Available from: https://doi.org/10.1016/j.mattod.2014.02.014

[9] TARASCON, J. M, ARMAND, M. Issues and challenges facing rechargeable lithium batteries. Nature [online]. 2001, 414, p. 359-367 [accessed 2019-06-21]. eISSN 1476-4687. Available from: https://doi.org/10.1038/35104644

[10] BECKER, J., SCHAEPER, CH., MUENNIX, J., SAUER, D. U., LAMMERING, T., SAUTERLEUTE, A., HAUBER, B., SCHNEIDER, T. Design of a safe and reliable Li-ion battery system for applications in airbone system. In: 52nd AIAA 
Aerospace Sciences Meeting - AIAA Science and Technology Forum and Exposition, SciTech 2014: proceedings [online]. Reston, VA: AIAA, 2014. eISBN 978-1-62410-256-1. Available from: https://doi.org/10.2514/6.2014-0380

[11] CHAMNAN-ARSA, S., UTHAICHANA, K., KAEWKHAM-AI, B. Modeling of LiFePO4 battery state of charge with recovery effect as a three-mode switched system. In: 13th International Conference on Control Automation Robotics and Vision ICARCV 2014: proceedings [online]. IEEE, 2014. p. 1712-1717. ISBN 978-1-4799-5199-4. Available from: https://doi.org/10.1109/ICARCV.2014.7064574

[12] CAI, Y., ZHANG, Z., ZHANG, Y., LIU, Y. A self-reconfiguration control regarding recovery effect to improve the discharge efficiency in the distributed battery energy storage system. In: 2015 IEEE Applied Power Electronics Conference and Exposition APEC: proceedings [online]. Charlotte, NC: IEEE, 2015. ISSN 1048-2334, eISBN 978-1-4799-6735-3, p. 1774-1778. Available from: https://doi.org/10.1109/APEC.2015.7104587

[13] CHIU, H.-J., LIN, L.-W., PAN, P.-L., TSENG, M.-H. A novel rapid charger for lead-acid batteries with energy recovery. IEEE Transactions on Power Electronics [online]. 2006, 21(3), p. 640-647. ISSN 0885-8993, eISSN 1941-0107. Available from: https://doi.org/10.1109/TPEL.2006.872386

[14] CACCIATO, M., NOBILE, G., SCARCELlA, G., SCELBA, G. Real-Time Model-Based Estimation of SOC and SOH for Energy Storage Systems. IEEE Transactions on Power Electronics [online]. 2017, 32(1), p. 794-803. ISSN 0885-8993, eISSN 1941-0107. Available from: https://doi.org/10.1109/TPEL.2016.2535321

[15] WINA LiFePO 3.2V 60Ah cell datasheet [online]. Available from: https://files.ev-power.eu/inc/_doc/attach/StoItem/4091/ ZG-LFP060AHA_datasheet.pdf 